\title{
Dominant sugar utilizers in sediment of Lake Constance depend on syntrophic cooperation with methanogenic partner organisms
}

\author{
Nicolai Müller, Benjamin M. Griffin, Ulrich Stingl and \\ Bernhard Schink ${ }^{\star}$ \\ Fachbereich Biologie, Universität Konstanz, D-78457 \\ Konstanz, Germany.
}

\section{Summary}

Six strains of novel bacteria were isolated from profundal sediment of Lake Constance, a deep freshwater lake in Germany, by direct dilution of the sediment in mineral agar medium containing a background lawn of the hydrogen-scavenging Methanospirillum hungatei as a syntrophic partner. The numbers of colony-forming units obtained after incubation for more than 2 months were in the same range as those of total bacterial counts determined by DAPI staining (up to $10^{8}$ cells per millilitre) suggesting that these organisms were dominant members of the community. Identical dilution series in the absence of methanogenic partners yielded numbers that were lower by two to three orders of magnitude. The dominant bacteria were isolated in defined co-culture with $M$. hungatei, and were further characterized. Growth was slow, with doubling times of $22-28 \mathrm{~h}$ at $28^{\circ} \mathrm{C}$. Cells were small, $0.5 \times 5 \mu \mathrm{m}$ in size, Gram-positive, and formed terminal oval spores. At $20^{\circ} \mathrm{C}$, glucose was fermented by the co-culture strain BoGlc83 nearly stoichiometrically to $2 \mathrm{~mol}$ of acetate and $1 \mathrm{~mol}$ of methane plus $\mathrm{CO}_{2}$. At higher temperatures, also lactate and traces of succinate were formed. Anaerobic growth depended strictly on the presence of a hydrogen-scavenging partner organism and was inhibited by bromoethane sulfonate, which together indicate the need for a syntrophic partnership for this process. Strain BoGlc83 grew also aerobically in the absence of a partner organism. All enzymes involved in ATP formation via glycolysis and acetyl CoA were found, most of them at activities

Received 3 August, 2007; accepted 21 December, 2007. *For correspondence. E-mail Bernhard.Schink@uni-konstanz.de; Tel. (+49) 7531 882140; Fax (+49) 7531884047 . Dedicated to Professor Dr Norbert Pfennig on occasion of his 82nd birthday. equivalent to the physiological substrate turnover rate. This new type of sugar-fermenting bacterium appears be the predominant sugar utilizer in this environment. The results show that syntrophic relationships can play an important role also for the utilization of substrates which otherwise can be degraded in pure culture.

\section{Introduction}

Only a small fraction, in the range of $0.1-1 \%$, of the total microbial community present in natural environments has been cultivated by conventional techniques (Staley and Konopka, 1985; Amann et al., 1995; Fry, 2000). In some cases, the cultivation efficiency could be improved substantially after design of better-adapted cultivation media and supply of specific growth factors such as signal molecules (Schut et al., 1993; Bussmann et al., 2001; Bruns et al., 2002). Cultivation-independent techniques for identification of microbes in situ, e.g. by hybridization with specific 16S rRNA-targeted probes, have helped to identify at least part of the non-cultivated microbial community (Giovannoni et al., 1990; Amann et al., 2001; Ramakrishnan et al., 2001). However, only in exceptional cases these techniques provide sufficient information on the metabolic capacities and the possible ecological function of the respective organisms (Wagner et al., 2002), and the cultivation and physiological characterization of the majority of microbes in natural habitats is still the most demanding challenge in microbial ecology.

In anoxic, sulfate-poor environments, biomass is converted mainly to methane and $\mathrm{CO}_{2}$ by a complex community of fermenting bacteria in cooperation with methanogens and homoacetogens which keep the hydrogen partial pressure in the range of $10^{-4}-10^{-5} \mathrm{~atm}$. (Schink, 1997; Schink and Stams, 2001). Under such conditions, the fermentation of sugars by fermenting bacteria such as Clostridium spp. or Ruminococcus albus is shifted from the production of reduced sideproducts such as butyrate or ethanol to nearly exclusive formation of acetate, $\mathrm{CO}_{2}$ and $\mathrm{H}_{2}$ (lanotti et al., 1973; Zeikus, 1977; Tewes and Thauer, 1980; Zeikus, 1983), according to the equation 
Table 1. Enumeration of sugar-fermenting bacteria in sediment of Lake Constance in the presence or absence of a methanogenic partner bacterium.

\begin{tabular}{lll}
\hline Substrate & Cultivation conditions & cfu ml \\
\hline Glucose & $-M$. hungatei & $1.2 \times 10^{5}$ \\
Starch & $+M$. hungatei & $1.4 \times 10^{8}$ \\
& $-M$. hungatei & $2.0 \times 10^{5}$ \\
Sucrose & $+M$. hungatei & $4.2 \times 10^{7}$ \\
& $-M$. hungatei & $8.0 \times 10^{4}$ \\
& $+M$. hungatei & $1.6 \times 10^{7}$ \\
\hline
\end{tabular}

Tubes were incubated at $28^{\circ} \mathrm{C}$ for 2 months. The total count (DAPI) was $8.7 \pm 0.5 \times 10^{7}$ cells per millilitre of sediment $(n=3)$.

$$
\begin{gathered}
\mathrm{C}_{6} \mathrm{H}_{12} \mathrm{O}_{6}+2 \mathrm{H}_{2} \mathrm{O} \rightarrow 2 \mathrm{CH}_{3} \mathrm{COO}^{-}+2 \mathrm{H}^{+}+2 \mathrm{CO}_{2}+4 \mathrm{H}_{2} ; \\
\Delta \mathrm{G}^{0^{\prime}}=-216 \mathrm{~kJ} \text { per mole. }
\end{gathered}
$$

Alternatively, formate could be formed instead of $\mathrm{H}_{2}$ with a similar energy yield $\left(-202 \mathrm{~kJ} \mathrm{~mol}^{-1}\right)$. Fermentation according to this equation does not provide sufficient energy for concomitant formation of 4 ATP which is linked directly to glycolytic sugar fermentation through substrate-level phosphorylation steps, which would require a minimum of $4 \times 60-70$ kJ per ATP (Thauer et al., 1977; Schink, 1997). At $10^{-4} \mathrm{~atm}$. hydrogen pressure, the reaction yields $317 \mathrm{~kJ}$ per mole, sufficient to allow synthesis of 4 ATP per mole of glucose. In pure culture therefore known sugarfermenting anaerobes produce butyrate, ethanol or lactate as side-products, leading to lower ATP yields.

In the present study, we tested the hypothesis that not all sugar-utilizing anaerobes fermenting hexoses according to the equation above would be able to shift to production of reduced side-products, and would therefore depend on syntrophic cooperation with hydrogen- or formate-oxidizing partners.

\section{Results}

Enrichment and isolation of anaerobic sugar oxidizers

Syntrophic sugar oxidizers were isolated in agar shake dilution series in sulfide-reduced mineral medium with Methanospirillum hungatei in the background. After 3 weeks of incubation at $28^{\circ} \mathrm{C}$, colonies were found in all dilution series to a maximum of $10^{5}$ colony-forming units (cfu) per millilitre of inoculum. Direct counting of the inoculum material after diamidino phenylindol (DAPI) staining revealed a total of $8.7 \pm 0.5 \times 10^{7}$ cells per millilitre $(n=3)$. After further incubation for another $6-8$ weeks, further small colonies became visible in the dilution series with the methanogenic partner, corresponding to $1.4 \times 10^{8} \mathrm{cfu}$ per millilitre of sediment with glucose, and $4.2 \times 10^{7}$ or $1.6 \times 10^{7}$ with starch and sucrose respectively (Table 1). These colonies were small, only about $0.1-0.5 \mathrm{~mm}$ in diameter, and were surrounded by satellite colonies of the methanogenic partner (Fig. 1A). No such colonies were found in dilution series without methanogenic partners. Finally, six strains of defined co-cultures were isolated in liquid medium from the tubes with glucose as substrate. These cultures contained, beyond M. hungatei, motile, short rod-shaped bacteria, 0.5-5 $\mu \mathrm{m}$ in size, which stained Gram-positive and formed subterminal spores in the stationary phase (Fig. 1B and C). Growth with glucose with all these strains was slow, with doubling times of 22-28 h. Addition of $5 \mathrm{mM}$ bromoethane sulfonate, a specific inhibitor of methanogens (Gunsalus et al., 1978), inhibited growth and substrate utilization in all these cultures. No growth was observed in spent medium. All isolates grew optimally with 2-3 mM glucose; higher substrate concentrations were inhibitory. Three strains were analysed with respect to their 16S rDNA
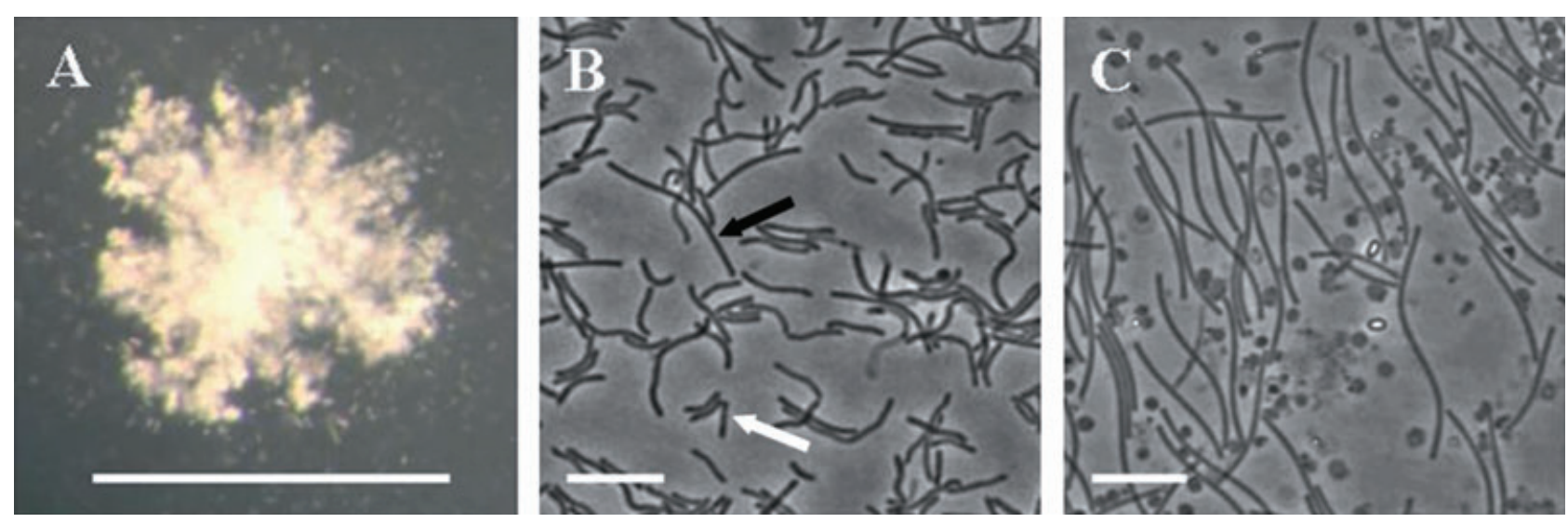

Fig. 1. Micrographs of strain BoGlc83.

A. Colony of strain BoGlc83 in agar medium surrounded by satellite colonies of Methanospirillum hungatei. Bar corresponds to $1 \mathrm{~mm}$. $\mathrm{B}$ and $\mathrm{C}$. Phase-contrast photomicrographs of cells of the co-culture. Bar corresponds to $10 \mu \mathrm{m}$. (B) Exponential growth phase cells. White arrow: strain BoGlc83; black arrow: M. hungatei. (C) Outgrown culture showing cells of M. hungatei, debris of lysed cells and spores of strain BoGlc83. 


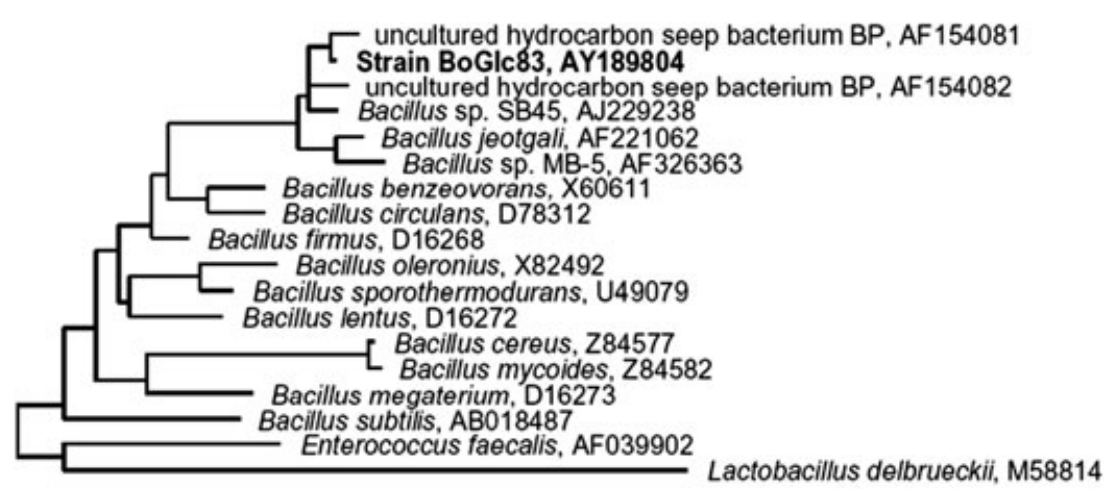

0.10
Fig. 2. $16 \mathrm{~S}$ rRNA gene-based phylogenetic tree showing the relation of strain BoGlc83 to other members of the Bacillales. The phylogenetic tree was constructed by utilizing a maximum-likelihood method implemented in ARB. Enterococcus faecalis and Lactobacillus delbrueckii were used as outgroup references. The scale bar represents 10 substitutions per $100 \mathrm{nt}$. sequences (see below). Because they exhibited identical sequences, only one of them, strain BoGlc83, was used for further investigation after repeated isolation of single colonies and pasteurization of liquid cultures for selective elimination of contaminants. No growth was observed if the co-culture was incubated with $0.05 \%(\mathrm{w} / \mathrm{v})$ yeast extract or $0.05 \%(\mathrm{w} / \mathrm{v})$ nutrient broth. Yeast extract provided with glucose did not enhance growth. A wide range of substrates including diverse sugars, organic acids and alcohols was checked for utilization by strain BoGlc83. Reproducible growth was observed only with glucose, fructose and maltose. Addition of alternative electron acceptors such as sulfate, nitrate or fumarate did not increase maximal optical densities reached. Aerobic growth of strain BoGlc83 was observed with glucose, fumarate or lactate, preferentially on complex media (e.g. SOC medium). With the co-culture of strain BoGlc83 and $M$. hungatei, $\mathrm{OD}_{578}$ of 0.1 corresponded to $26.4( \pm 3) \mathrm{mg}$ cell dry mass per litre.

Similar dilution experiments with pasteurized sediment samples after incubation for 2.5 months yielded numbers of cfu that were by three orders of magnitude lower than the maximum numbers documented in Table 1, indicating that the predominant fraction of these bacteria was present in the sediment as metabolically active cells, not as spores.

In order to find alternative anaerobic cultivation conditions for strain BoGlc83, pasteurized samples of aerobically grown cells were inoculated in media with Methanobrevibacter arboriphilus in the background which can only use molecular hydrogen as energy source. Parallel incubation of the spores with $M$. hungatei helped to insure that restorage of anaerobic growth is possible after cultivation in oxic medium. Although a small increase of optical density was observed $\left(\Delta \mathrm{OD}_{578}\right.$ maximally 0.064 after 7 days of incubation), no significant accumulation of fermentation products was detected. Anaerobic growth was fully restored in cultures with the formate plus hydrogen utilizing $M$. hungatei as syntrophic partner.

\section{Phylogenetic characterization}

For classification of the isolated strains, the 16S rRNA gene of three strains was amplified with primers targeting the bacterial domain, sequenced, and compared with the $\mathrm{NCBI}$ database. The sequences of all three strains were identical and showed the highest sequence similarities with representatives of the low GC Gram-positive bacteria, with Bacillus jeotgali (Yoon et al., 2001) as the only described species (Fig. 2). Another strain in the same cluster has been described as an iron-reducing bacterium dominant in rice paddies (Chin et al., 1999); other sequences from this cluster refer to uncultivated strains.

\section{Fermentation pattern}

Growth experiments and chromatographic analysis of the culture supernatant revealed that glucose was fermented to acetate, minor amounts of lactate, and a very small amount of succinate which was detected only with glucose concentrations higher than $2 \mathrm{mM}$ (Tables 2 and 3 ). The peaks of standards of other possible fermentation products (formate, propionate, butyrate, acetoin, 2,3butanediol or ethanol) were clearly separated from those of the detected substances. After addition of $1 \mathrm{mM}$ of the respective substances as internal standards to the samples prior to analysis, no additional peaks or split peaks could be detected in the chromatograms.

Increasing cultivation temperatures caused a metabolic shift towards enhanced lactate formation (Table 2). At $20^{\circ} \mathrm{C}$, the cells converted glucose almost completely to acetate, $\mathrm{CO}_{2}$ and methane. The final concentrations of all metabolites were stable for at least $375 \mathrm{~h}$ at all temperatures. Cultures grown at $30^{\circ} \mathrm{C}$ or $40^{\circ} \mathrm{C}$ produced significantly more lactate and less acetate and methane than cultures incubated at $20^{\circ} \mathrm{C}$ (Fig. 3). Cultures inhibited by $5 \mathrm{mM}$ BES produced only small amounts of acetate, lactate and formate, with no significant increase in $\mathrm{OD}_{578}$ (Table 2). No accumulation of hydrogen 
Table 2. Fermentation products after growth at different temperatures on $2 \mathrm{mM}$ glucose.

\begin{tabular}{|c|c|c|c|c|c|c|}
\hline & \multicolumn{6}{|c|}{ End concentrations after $230 \mathrm{~h}$ of incubation $(\mathrm{mM})^{\mathrm{a}}$} \\
\hline & \multicolumn{3}{|c|}{ Co-culture } & \multicolumn{3}{|c|}{ Co-culture $+5 \mathrm{mM}$ BES } \\
\hline & $20^{\circ} \mathrm{C}$ & $30^{\circ} \mathrm{C}$ & $40^{\circ} \mathrm{C}$ & $20^{\circ} \mathrm{C}$ & $30^{\circ} \mathrm{C}$ & $40^{\circ} \mathrm{C}$ \\
\hline Glucose & 0 & 0 & 0 & 1.70 & 1.47 & 1.62 \\
\hline Acetate $^{b}$ & 2.89 & 2.64 & 2.35 & 0.20 & 0.30 & 0.17 \\
\hline Lactate & 0.15 & 0.41 & 0.90 & 0.18 & 0.51 & 0.36 \\
\hline Formate & 0 & 0 & 0 & 0.17 & 0.31 & 0 \\
\hline Methane & 1.21 & 1.24 & 0.94 & 0.02 & 0.02 & 0.04 \\
\hline
\end{tabular}

a. Volumes at the end of the experiment: headspace $35 \mathrm{ml}$; culture $25 \mathrm{ml}$.

b. Values corrected for initial acetate concentration resulting from inoculum.

was detected in BES-inhibited cultures (detection limit $10^{-3}$ bar).

In another experiment, stoichiometries of glucose oxidation were calculated. Fermentation product analysis in eight parallel assays proved equilibrated electron balances. The amount of produced lactate increased significantly at higher initial glucose concentrations (Table 3).

Accumulation of the above-mentioned fermentation products was occasionally observed also in aerobic cultures.

\section{Enzyme activities}

In order to investigate the metabolic pathways of syntrophic glucose oxidation in strain BoGlc83, enzyme assays were carried out with cell-free extracts. Activities of all key enzymes of the classical Embden-MeyerhofParnas pathway were detected (Table 4). Pyruvate is oxidized most likely via the Clostridium-type fermentation enzymes pyruvate:ferredoxin oxidoreductase, phosphotransacetylase and acetate kinase (Table 4). No activity of lactate dehydrogenase (LDH) was found, neither with $\mathrm{NAD}^{+}$nor with dichlorophenol-indophenol (DCPIP) as electron acceptor. Addition of known allosteric activators of LDH like fructose-1,6-bisphosphate did not help to initiate the reaction. Fructose-1,6-bisphosphate aldolase, glyceraldehyde-3-phosphate dehydrogenase and pyruvate kinase required reduced assay conditions which were obtained by addition of DTE. Pyruvate kinase activity was enhanced by addition of $\mathrm{NH}_{4} \mathrm{Cl}$. Pyruvate was oxidized to acetyl coenzyme A by pyruvate:ferredoxin oxidoreductase, as indicated by the coenzyme A- and pyruvate-dependent reduction of benzyl viologen. No indication of pyruvate:formate lyase or formate: $\mathrm{H}_{2}$ lyase was obtained. The presence of formate dehydrogenase (FDH) and hydrogenase $\left(\mathrm{H}_{2}\right.$ :benzyl viologen oxidoreductase) in French-Press extracts shows that formate or hydrogen could be released from reduced ferredoxin. High FDH and no hydrogenase activity was detected in cell-free extracts produced by selective cell lysis with mutanolysin. FDH activities were detected only with benzylviologen or methylviologen as electron acceptors and no activity was observed with $\mathrm{NAD}^{+}$or $\mathrm{NADP}^{+}$. Most enzyme activities varied with the growth state of the cells (Table 4). In contrast, triosephosphate isomerase and phosphotransacetylase were present always at comparably high activities $\left(>1 \mathrm{U} \mathrm{mg}^{-1}\right)$. It was not possible to measure acetate kinase in the direction of acetyl-phosphate and ADP formation from acetate and ATP. Therefore, a discontinuous assay was adapted to measure acetyl-phosphate decrease.

\section{Discussion}

The novel bacteria described in the present study differ from known fermenting bacteria in a series of unusual properties. They depend for fermentative degradation of hexoses on a syntrophic cooperation with a putatively hydrogen-utilizing methanogenic partner bacterium. Moreover, they appear to be the dominant sugar utilizers

Table 3. Stoichiometry of fermentation of strain BoGlc83.

\begin{tabular}{|c|c|c|c|c|c|c|c|c|c|}
\hline \multirow{2}{*}{$\begin{array}{l}\text { Glucose } \\
\text { provided }^{\text {a }}\end{array}$} & \multirow{2}{*}{$\begin{array}{l}\text { maximum } \\
\mathrm{OD}_{578}{ }^{\mathrm{a}}\end{array}$} & \multirow{2}{*}{$\begin{array}{l}\text { Cell dry mass } \\
\text { formed }(\mathrm{mg})^{\mathrm{b}}\end{array}$} & \multirow{2}{*}{$\begin{array}{l}\text { Substrate } \\
\text { assimilated } \\
(\mu \mathrm{mol})^{c}\end{array}$} & \multirow{2}{*}{$\begin{array}{l}\text { Substrate } \\
\text { dissimilated } \\
(\mu \mathrm{mol})\end{array}$} & \multicolumn{4}{|c|}{ Products formed $(\mu \mathrm{mol})^{\mathrm{a}}$} & \multirow{2}{*}{$\begin{array}{l}\text { Electron } \\
\text { recovery } \\
(\%)\end{array}$} \\
\hline & & & & & Acetate & Lactate & Succinate & Methane & \\
\hline $2.02 \mathrm{mM}$ & 0.112 & 1.47 & 10.11 & 90.89 & 145.5 & 18.5 & 2.5 & 92.4 & 98.3 \\
\hline $5.35 \mathrm{mM}$ & 0.16 & 2.108 & 14.5 & 253 & 367 & 78.5 & 18.5 & 218.4 & 95 \\
\hline
\end{tabular}

a. Mean values from eight $120 \mathrm{ml}$ serum bottles with $50 \mathrm{ml}$ of culture and $70 \mathrm{ml}$ headspace.

b. Calculated from the above-determined correlation factor: $\mathrm{OD}_{578} 0.1=26.35 \mathrm{mg} \mathrm{l}^{-1}$.

c. Assimilation equation: $17 \mathrm{C}_{6} \mathrm{H}_{12} \mathrm{O}_{6} \rightarrow 24<\mathrm{C}_{4} \mathrm{O}_{3} \mathrm{H}_{7}>+6 \mathrm{HCO}_{3}{ }^{-}+12 \mathrm{H}_{2} \mathrm{O}+6 \mathrm{H}^{+}$. 

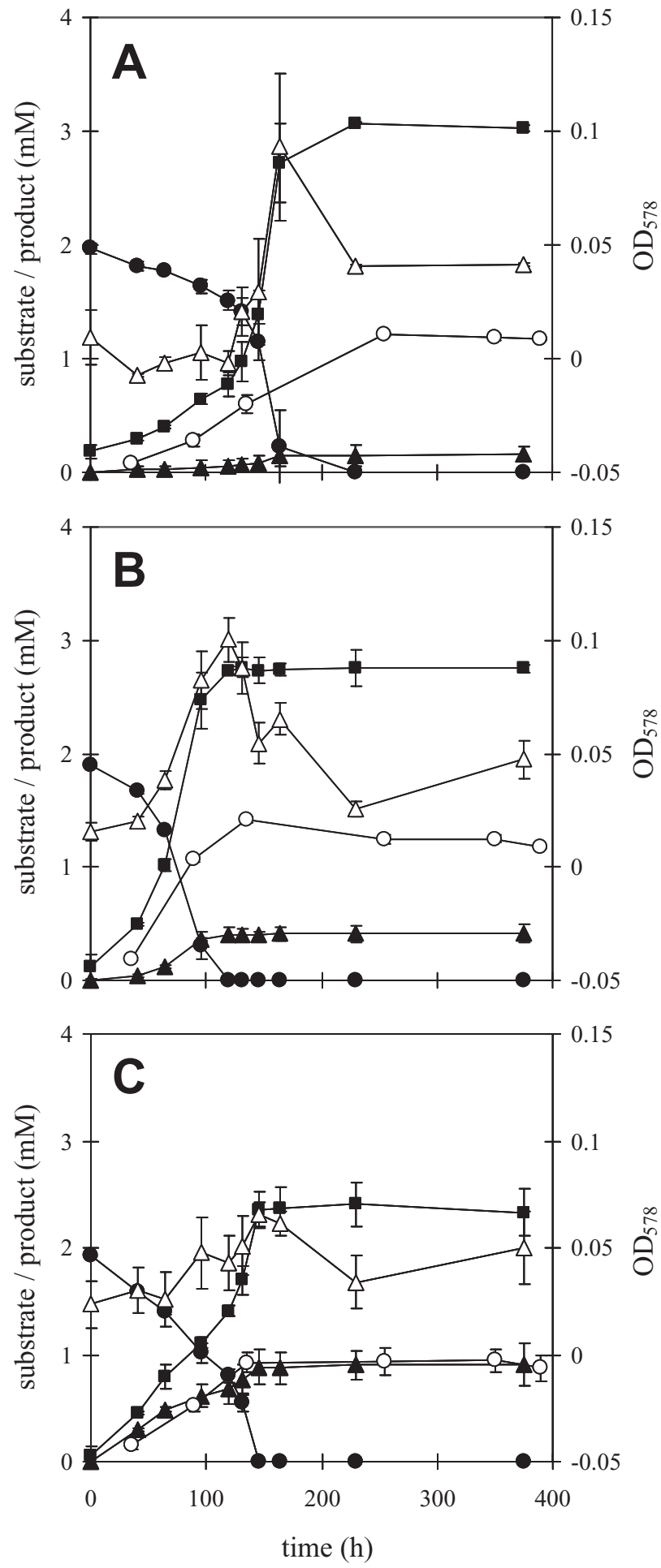

Fig. 3. Time-course of glucose fermentation by the BoGlc83 coculture. Incubation temperatures: (A) $20^{\circ} \mathrm{C}, n=2$; (B) $30^{\circ} \mathrm{C}$, $n=3$; (C) $40^{\circ} \mathrm{C}, n=3$. Shown are mean values \pm standard deviations of $\mathrm{OD}_{578}$ (open triangles) and concentrations of glucose (filled circles), acetate (filled squares), lactate (filled triangles) and methane (open circles). Some error bars are smaller than symbol size. in a deep lake sediment, with total numbers ranging in the same order of magnitude as that of the total DAPI counts. Finally, they are spore-forming, facultatively anaerobic bacteria which have to be associated on the basis of $16 \mathrm{~S}$ rRNA sequence comparisons with aerobic Bacillus representatives.

\section{Physiology}

Degradation of glucose by strain BoGlc83 depends on the cooperation with a formate- or hydrogen-scavenging methanogenic partner. Dependence of sugar degradation on a syntrophic partner bacterium has so far been described only for Syntrophococcus sucromutans (Krumholz and Bryant, 1986), a homoacetogenic bacterium that lacks formate dehydrogenase and depends for that reason on cooperation with partners (Doré and Bryant, 1990). Another case of a fermenting bacterium which catalyses an exergonic reaction but needs cooperation with a syntrophic partner is Gelria glutamica, a thermophilic, glutamate-degrading anaerobe which requires a hydrogen-scavenging partner for glutamate degradation but can grow in pure culture with pyruvate, lactate, glycerol or several sugars (Plugge et al., 2002). Otherwise, hydrogen-, formate- or acetate-scavenging partners are required mainly in fermentative degradation of alcohols, fatty acids, certain amino acids and some other cases because these reactions can provide energy for growth only if electrons are removed, e.g. as hydrogen at low partial pressures $\left(10^{-4}-10^{-5}\right.$ atm.; Schink, 1997; Schink and Stams, 2001).

Strain BoGlc83 ferments glucose in cooperation with $M$. hungatei roughly according to the equation

$$
\mathrm{C}_{6} \mathrm{H}_{12} \mathrm{O}_{6}+2 \mathrm{H}_{2} \mathrm{O} \rightarrow 2 \mathrm{CH}_{3} \mathrm{COO}^{-}+2 \mathrm{H}^{+}+\mathrm{CO}_{2}+\mathrm{CH}_{4} \text {. }
$$

Traces of lactate and succinate were formed mainly at enhanced temperatures. Formation of formate as a fermentation side-product, lack of hydrogenase activity in selectively prepared cell-free extracts, and preferential syntrophic growth with $M$. hungatei rather than with $M$. arboriphilus indicate that strain BoGlc83 catalyses the reaction

$$
\mathrm{C}_{6} \mathrm{H}_{12} \mathrm{O}_{6}+2 \mathrm{H}_{2} \mathrm{O}+2 \mathrm{CO}_{2} \rightarrow 2 \mathrm{CH}_{3} \mathrm{COO}^{-}+4 \mathrm{HCOO}^{-}+6 \mathrm{H}^{+}
$$

although we cannot rule out that some electrons may be released also in the form of hydrogen. This reaction yields -202 kJ per mole of glucose under standard conditions, which is not sufficient to synthesize 4 mol ATP per mole of glucose. Fermentation of hexoses to exclusively acetate and formate or $\mathrm{H}_{2} / \mathrm{CO}_{2}$ becomes more exergonic at enhanced temperatures $(-275 \mathrm{~kJ}$ per mole of glucose at $80^{\circ} \mathrm{C}$ ), and some thermophilic bacteria have been described that ferment sugars accordingly (e.g. Soutschek et al., 1984; Rainey et al., 1991). However, 
Table 4. Enzyme activities in cell-free extracts.

\begin{tabular}{ll}
\hline Enzyme & Specific activity (U per milligram of protein) \\
\hline Hexokinase $^{\mathrm{a}}$ & $0.127-0.242$ \\
Phosphofructokinase $^{\mathrm{a}}$ & $0.145-0.291$ \\
Aldolase $^{\mathrm{a}}$ & $0.028-0.121$ \\
Triosephosphate isomerase $^{\mathrm{a}}$ & $0.242-1.04$ \\
Glyceraldehyde-3-P-dehydrogenase (NAD-reducing) $^{\mathrm{a}}$ & $0.129-0.659$ \\
Phosphoglycerate kinase $^{\mathrm{b}}$ & 0.571 \\
Pyruvate kinase $^{\mathrm{a}}$ & $0.039-0.274$ \\
Pyruvate:acceptor-oxidoreductase (Benzyl viologen) $^{\mathrm{c}}$ & 0.188 \\
Formate dehydrogenase (benzylviologen) $^{\mathrm{d}}$ & 3.20 \\
Formate dehydrogenase (methylviologen) $^{\mathrm{d}}$ & 1.72 \\
Hydrogenase (benzylviologen) $^{\mathrm{b}, \mathrm{c}}$ & 0.436 \\
Phosphotransacetylase $^{\mathrm{a}}$ & $1.53-2.67$ \\
Acetate kinase $^{\mathrm{c}}$ & 0.290
\end{tabular}

a. Minimal and maximal activities from at least three independent cell-free extracts of different growth stages.

b. Hydrogenase activity was not measured in extracts selectively prepared with mutanolysin.

c. Mean values from at least three measurements in one cell-free extract.

d. Measured in mutanolysin extracts. Activities comparable to those observed in French-Press extracts.

re-examination of the fermentation patterns of these bacteria in our laboratory could not reproduce these fermentation balances. Either the substrate conversion was incomplete, and only a small fraction of the substrate was converted, or side-products were formed by simultaneous fermentation of complex medium additions such as yeast extract, etc., thus rendering an exact analysis of the fermentation balance difficult $(H$. Miller and B. Schink, unpubl. results). The energetic situation can be substantially improved if the hydrogen or formate concentration is lowered to $10^{-4}$ atm. or $10^{-4} \mathrm{M}$, respectively, e.g. by the activity of a methanogenic partner, changing the overall free energy change to $-290 \mathrm{~kJ}$, and thus allowing the synthesis of 4 ATP per mole of glucose. Our enzyme measurements confirm that glucose is degraded in our strain through the Embden-Meyerhof pathway, and in particular the enzymes responsible for ATP synthesis, i.e. 3-phosphoglycerate kinase and pyruvate kinase, as well as phosphotransacetylase and acetate kinase are present at sufficient activity to support our concept of this metabolism. With this, strain BoGlc83 represents an extreme case of the known behaviour of Clostridium butyricum, $R$. albus and others which carry out the same fermentation at low hydrogen pressure but can shift to formation of other, reduced fermentation products in pure culture if needed (Tewes and Thauer, 1980; Schink and Zeikus, 1982). Unlike those, strain BoGlc83 is unable to use alternative fermentations to optimize its energy metabolism in the absence of a suited partner. It is also surprising how specialized this organism is on the utilization of only three sugars which all are degraded anaerobically only in the presence of a partner organism. No growth was found with any substrate in the absence of a partner, and no growth was found either in mixed culture if the methanogenic partner was inhibited by bromoethane sulfonate. Strain BoGlc83 also represents the first case of a facultatively aerobic bacterium which can shift under anoxic conditions to a syntrophic mode of metabolism. This is especially surprising because obligately syntrophic fermenting bacteria require a specific set of reversed electron transport systems (Mclnerney et al., 2007) which differ substantially from aerobic electron transport.

\section{Ecology}

Fermenting bacteria similar to strain Glc83 were found to outnumber classical sugar-fermenting bacteria by two to three orders of magnitude. Obviously, this new type of syntrophic sugar fermentation is the dominant type of sugar fermentation in such an anoxic environment of longterm stability, with slow but continuous input of organic matter and lack of significant environmental challenges such as bioturbation, temperature shifts or other changes. Under these conditions, this new type of sugar fermentation yields optimal energy, and there is very little chance that the bacterium has to adapt to varying life conditions over time. As well, our strains are slow compared with classical sugar fermenters, with doubling times of more than 1 day under optimal conditions at $28^{\circ} \mathrm{C}$. Thus, isolation of these organisms in visible colonies in the presence of the partner organism needed incubation times of 2-3 months whereas the usual, fast-growing fermenters showed visible colonies already after 2-3 weeks. Our new strains therefore appear to constitute the 'autochthonous' sugar-degrading community in this environment, whereas the fast-growing competitors are the 'zymogenous' representatives (sensu Winogradsky, 1949). Attribution of these new bacteria to this ecophysiological group is further supported by the fact that they are obviously adapted only to low substrate concentrations, and that glucose at concentrations higher than $2 \mathrm{mM}$ inhibited 
growth significantly. Although they are able to form spores, our counting experiments with pasteurized sediment material indicate that these cells were not at a dormant state in the sediment but physiologically active, probably at very low substrate turnover rates.

The growth yields we obtained in our cultures were far lower than one would expect from a metabolism yielding 4 ATP per mole of glucose. With bacteria growing with glucose, a $Y_{\text {ATP }}$ of roughly 10-12 g per mole of ATP would be expected, i.e. 40-50 g per mole of glucose. The yields we observed were far less than that, roughly one-quarter of the expected value. This low value may be due to the comparably slow growth and the concomitant high expenditures into maintenance energy. Moreover, we observed that the growth yield is obviously not an easy, linear function of the amount of substrate provided, and that the highest growth yields were observed with the lowest substrate concentrations used. This effect could only partly be compensated by addition of a further buffering system, indicating either that the small accumulations of acetate inhibited growth, e.g. by partial depolarization of the cytoplasmic membrane, or that the bacteria have a basic problem dealing with enhanced substrate concentrations in general. The non-linear dependence of growth yields on substrate supply may also be due to the observed enhanced formation of lactate, concomitant with lower energy yields and decreased support of the methanogenic partner. Thus, the growth yield data documented here are only of preliminary value and might have to be challenged again, e.g. by growth studies in chemostats.

\section{Taxonomy}

According to classical taxonomy, a facultatively anaerobic, spore-forming, fermenting bacterium should be attributed to the genus Bacillus (Sneath, 1986). Sequence similarity analysis of the 16S rRNA and comparison with related strains suggest to attribute these new strains among several bacteria that are known so far only through sequence comparison from environmental samples, and have not been cultivated yet. The only relatives that have been described so far in defined cultures appear to be aerobic bacteria belonging to the genus Bacillus; the closest physiologically characterized representative is B. jeotgali (Yoon et al., 2001). Also other Bacillus species have been described to change to a fermenting type of metabolism (Sneath, 1986); however, syntrophic cooperation with methanogens has not been documented so far.

\section{Experimental procedures}

\section{Sources of microorganisms}

Strain BoGlc83 was enriched from profundal sediments of Lake Constance, Constance, Germany and deposited at the
German strain collection (DSM 19598). Methanospirillum hungatei strain Mh1 was isolated in our lab from the same source and $M$. arboriphilus strain $\mathrm{DH} 1$ was purchased from the DSM (No. 1125).

\section{Sampling sites}

Sediment samples were taken from cores of Lake Constance sediment at about $80 \mathrm{~m}$ water depth, about $1-2 \mathrm{~cm}$ below the sediment surface, at the transition from a grey surface layer to a blackish, sulfidic sediment below. Oxygen penetrates into this sediment only to $5 \mathrm{~mm}$ depth at maximum (Hauck et al., 2001). Sediment material was homogenized with sterile, anoxic mineral medium by vigorous shaking, and subsequently diluted in 1:10 steps in agar shake cultures in the same medium. Glucose, sucrose (both $2 \mathrm{mM}$ ) or soluble starch $\left(0.5 \mathrm{~g} \mathrm{l}^{-1}\right)$ was used as substrate, with $2 \mathrm{mM}$ acetate as background co-substrate, with and without a background lawn of $M$. hungatei strain $\mathrm{M} 1 \mathrm{~h}$ (about $10^{7}$ cells per millilitre).

\section{Medium and growth conditions}

Bacteria were cultivated in a bicarbonate-buffered, sulfidereduced anoxic freshwater mineral medium (Widdel and Bak, 1992). Trace elements, selenate and tungstate and a sevenvitamin solution were added from 1000 times concentrated stock solutions (Widdel et al., 1983). In order to minimize iron sulfide precipitation, a new trace element stock solution SL 13 was developed containing the same components as the original solution $\mathrm{SL} 10$, but the $\mathrm{FeCl}_{2}$ concentration was adjusted to $5 \mathrm{mM}$, with $14 \mathrm{mM}$ EDTA. Resazurin was added as redox indicator at a concentration of $0.4 \mathrm{mg}$ per litre.

The medium was prepared in $4 \mathrm{I}$ flasks, autoclaved at $121^{\circ} \mathrm{C}$ and 1 bar overpressure for $40 \mathrm{~min}$ and distributed to $1 \mathrm{l}$ infusion bottles or $120 \mathrm{ml}$ serum bottles $(70 \mathrm{ml}$ headspace) which were sealed with rubber septa under a headspace of $\mathrm{N}_{2} / \mathrm{CO}_{2}$ (80:20). Substrates and other additions were added from filter-sterilized stock solutions. Cultures were incubated at $28-30^{\circ} \mathrm{C}$ in the dark and optical densities were measured at $578 \mathrm{~nm}$ in a Uvikon 860 double-beam photometer (Kontron, Zürich, $\mathrm{CH}$ ) against oxic medium to correct for the absorption of oxidized resazurin.

Pure cultures were obtained by repeated serial dilution in agar medium (Widdel and Bak, 1992). Additionally, cultures were pasteurized at $80^{\circ} \mathrm{C}$ for $30 \mathrm{~min}$ after growth and spore formation, and afterwards transferred to fresh medium with a background lawn of $M$. hungatei (5 ml of an outgrown $M$. hungatei culture added to $50 \mathrm{ml}$ of medium). Purity was checked microscopically in cultures grown in mineral media with 2-10 mM glucose, 2-10 mM fumarate, or in media containing $0.05 \%(\mathrm{w} / \mathrm{v})$ yeast extract or $0.05 \%(\mathrm{w} / \mathrm{v})$ Nutrient broth plus $2 \mathrm{mM}$ glucose.

For aerobic cultivation, SOC medium was used (Sambrook et al., 1989) in sterile cotton-stoppered Erlenmeyer flasks or tubes on a rotary shaker at 200 r.p.m.

Spent media were prepared by filter sterilization of cultures of $M$. hungatei or the co-culture (BoGlc83 plus $M$. hungatei) through $0.2 \mu \mathrm{m}$ cellulose acetate filters FP 30/0.2 CA-S (Whatman, Dassel, Germany). Filtrates were used undiluted 
or mixed with fresh medium in various amounts. Finally, $2 \mathrm{mM}$ glucose and $5 \mathrm{mM}$ BES were added.

\section{DNA extraction}

Aliquots of $2 \mathrm{ml}$ from co-cultures of $M$. hungatei with strains BoGlc81, BoGlc83 and BoGlc85, respectively, were centrifuged (10 $000 \mathrm{~g}, 15 \mathrm{~min}$ ) and the supernatant was discarded. DNA from the pellets was extracted using a bead-beating method (Henckel et al., 1999), purified with the EZNA cycle pure kit (peqlab, Erlangen, Germany) and eluted with $50 \mu \mathrm{l}$ of sterile water.

\section{Polymerase chain reaction of bacterial 16S rRNA genes and phylogenetic analysis}

Bacterial 16S rRNA genes were amplified using primers $27 \mathrm{~F}$ (5'-AGA GTT TGA TCC TGG CTC AG-3'; Escherichia coli position 8-27) (Edwards et al., 1989) and 1492R (5'-TAC GGY TAC CTT GTT ACG ACT T-3'; E. coli position 14921512) (Weisburg et al., 1991) using $1 \mu \mathrm{l}$ of the extracted DNA as template. Polymerase chain reaction (PCR) (30 cycles) was carried out as described previously (Henckel et al., 1999), except that the annealing temperature was $55^{\circ} \mathrm{C}$. Polymerase chain reaction products were purified with the QIAquick PCR purification kit (Qiagen, Hilden, Germany) and partially sequenced using the $27 \mathrm{~F}$ primer (GATC, Konstanz, Germany). As nearly identical sequences (sequence similarity $>99.5 \%$ ) were obtained with the three isolates, only the 16S rRNA gene of strain BoGlc83 was further sequenced with primers 533F, 907F and 1492R (Stingl et al., 2004).

Sequences were assembled using DNAStar (http://www. dnastar.com). Sequence data were analysed using the ARB software package (version 2.5b; http://www.arb-home.de; Ludwig et al., 1997). The new sequences were added to the ARB database and aligned using the Fast Aligner tool implemented in ARB. Alignments were checked and manually corrected where necessary. Sequences were compared with 16S rRNA gene sequences in public databases using BLAST (Altschul et al., 1990); sequences with high similarities to those determined in this study were retrieved and added to the alignment. Highly variable regions of the 16S rRNA gene sequences and sequence positions with possible alignment errors were excluded by using only those positions of the alignment that were identical in at least $50 \%$ of all sequences. The phylogenetic tree was calculated using fastDNAml (Olsen et al., 1994), a maximum-likelihood method implemented in ARB, using only almost full-length sequences (> 1300 bases). The stability of the branching pattern was verified using the neighbour-joining and maximum-parsimony (DNAPARS) methods included in the PHYLIP package (Felsenstein, 1989) implemented in ARB.

$16 S$ rDNA sequences of strain BoGlc83 obtained in this study were deposited with GenBank under the Accession No. AY 189804.

\section{Growth experiments}

Sterile $60 \mathrm{ml}$ serum bottles containing $30 \mathrm{ml}$ of medium with $2 \mathrm{mM}$ glucose were inoculated with $3 \mathrm{ml}$ of an exponentially growing pre-culture. Controls contained either inoculum, $2 \mathrm{mM}$ glucose and $5 \mathrm{mM}$ bromoethane sulfonate (BES), or $2 \mathrm{mM}$ glucose and no inoculum. Samples were withdrawn with syringes from the cultures as well as from the headspace for product determination. Cultures were incubated at $20^{\circ} \mathrm{C}$, $30^{\circ} \mathrm{C}$ and $40^{\circ} \mathrm{C}$, respectively, in thermoconstant rooms or incubators. For determination of electron balances and fermentation stoichiometries, $120 \mathrm{ml}$ serum bottles with $50 \mathrm{ml}$ of medium and $70 \mathrm{ml}$ headspace were used.

\section{Quantification of cell dry mass}

Bacteria were cultivated in three $1 \mathrm{I}$ infusion bottles containing growth medium with $2 \mathrm{mM}$ glucose from the same 4 I batch. Trace element solution SL 13 was used to avoid FeS precipitates in the medium. Cells were harvested exactly at the time point when glucose was totally consumed and before spore formation started. The $\mathrm{OD}_{578}$ was recorded and the cultures were centrifuged at $13500 \mathrm{~g}$ for $5 \mathrm{~min}$ at $4^{\circ} \mathrm{C}$ in 20 steps using $50 \mathrm{ml}$ polypropylene tubes (Deltalab, Barcelona, Spain) which were dried to constant weight before use in a lyophilizer Alpha 1--4/LDC-1 M (Christ, Osterode, Germany). Cells of three 1 I cultures were sedimented, the pellets frozen in liquid nitrogen, and lyophilized to constant weight. Cell dry mass was calculated from the mass differences of the tubes.

\section{Preparation of cell-free extracts}

Cultures grown in $1 \mathrm{I}$ medium were harvested at the end of the exponential phase in an anoxic chamber (Coy, Ann Arbor, MI, USA) by centrifuging the culture in anoxic polypropylene centrifuge bottles at $16270 \mathrm{~g}$ for $10 \mathrm{~min}$ at $4^{\circ} \mathrm{C}$ in a Sorvall RC-5B centrifuge (Du Pont de Nemours, Bad Homburg, Germany). Cells were washed once by re-suspending the pellet in the same volume of anoxic $0.1 \mathrm{M}$ Tris- $\mathrm{HCl}$ buffer, $\mathrm{pH} 7.6$, followed by centrifugation as described above. The pellet was re-suspended in 4-6 $\mathrm{ml}$ of washing buffer and cells were broken by repeated passage through a cooled FrenchPressure cell at $137 \mathrm{MPa}$ pressure under anoxic conditions. Alternatively, eubacterial cells were opened selectively by treatment with mutanolysin as described before (Wallrabenstein and Schink, 1994). Cell debris was removed anoxically by centrifugation (Optima TL-ultracentrifuge, TLA-100.4rotor; Beckman, München, Germany) at $30373 \mathrm{~g}$ for $20 \mathrm{~min}$ and the supernatant (cell-free extract) was stored under $\mathrm{N}_{2}$ on ice. Cultures grown in larger volumes were harvested by centrifugation in anoxic $120 \mathrm{ml}$ infusion bottles gassed with $\mathrm{N}_{2}$ as described before, with the same washing buffer as mentioned above (Brune and Schink, 1990).

\section{Enzyme assays}

Enzyme activities were measured continuously by following absorption changes with a spectrophotometer 100-40 (Hitachi, Tokyo, Japan) connected to an analogous recorder (SE 120 Metrawatt, BBC Goerz, Vienna, Austria). Assays were performed anoxically in a volume of $1 \mathrm{ml}$ in rubberstoppered cuvettes at $25^{\circ} \mathrm{C}$. Additions were made with microlitre syringes from anoxic stock solutions. One unit of specific enzyme activity was defined as $1 \mu \mathrm{mol}$ of substrate 
or product per minute at $25^{\circ} \mathrm{C}$, and normalized to milligram of protein unless specified otherwise.

Hexokinase (EC 2.7.1.1) was measured with a method modified after Wood (1971). The assay mixture contained $66 \mathrm{mM}$ triethanolamine- $\mathrm{HCl}$ (TEA-HCl) buffer, $\mathrm{pH} 7.6$, $2.5 \mathrm{mM}$ ATP, $1.3 \mathrm{mM} \mathrm{MgCl}_{2}, 0.33 \mathrm{mM} \mathrm{NADP}^{+}, 0.1$ units of glucose 6-phosphate dehydrogenase (yeast) per millilitre, and $50 \mu \mathrm{l}$ of cell-free extract. The reaction was started by addition of $1 \mathrm{mM}$ glucose and was measured as NADPH absorption increase at $340 \mathrm{~nm}\left(\varepsilon=6.22 \mathrm{mM}^{-1} \mathrm{~cm}^{-1}\right)$.

Phosphofructokinase (EC 2.7.1.11) was measured as $\mathrm{NADH}$ decrease coupled to aldolase, triosephosphate isomerase and glycerophosphate dehydrogenase (modified after Kemerer et al., 1975). The assay consisted of $75 \mathrm{mM}$ Tris- $\mathrm{HCl}, \mathrm{pH} 7.6,0.43 \mathrm{mM} \mathrm{NADH}, 1.3 \mathrm{mM} \mathrm{MgCl}, 1.7 \mathrm{mM}$ ATP, $0.7 \mathrm{U} \mathrm{ml}^{-1}$ aldolase (rabbit muscle), $25 \mathrm{U} \mathrm{ml}^{-1}$ triosephosphate isomerase, $2.5 \mathrm{U} \mathrm{ml}^{-1}$ glycerophosphate dehydrogenase (rabbit muscle) and 10-50 $\mu$ of cell-free extract. The reaction was initiated by addition of $6.7 \mathrm{mM}$ fructose-6phosphate.

The reaction mixture for fructose-bisphosphate aldolase (EC 4.1.2.13) contained $78 \mathrm{mM}$ TEA-HCl, $\mathrm{pH} 7.6$, with $3 \mathrm{mM}$ dithioerythritol (DTE), $0.26 \mathrm{mM} \mathrm{NADH}, 10 \mathrm{U} \mathrm{ml}^{-1}$ triosephosphate isomerase, $1 \mathrm{U} \mathrm{ml}^{-1}$ glycerophosphate dehydrogenase and $50 \mu \mathrm{l}$ of cell-free extract. The reaction was started by addition of $0.3 \mathrm{mM}$ fructose-1,6-bisphosphate (modified after Wood, 1971).

For measurement of triosephosphate isomerase activity (EC 5.3.1.1), $85 \mathrm{mM}$ Tris- $\mathrm{HCl}, \mathrm{pH} 7.6,0.26 \mathrm{mM} \mathrm{NADH}$, $2 \mathrm{U} \mathrm{ml}^{-1}$ glycerophosphate dehydrogenase (rabbit muscle) and $50 \mu \mathrm{l}$ of cell-free extract were provided in the cuvette. Addition of $2 \mathrm{mM}$ glyceraldehyde-3-phosphate started the reaction (modified after Takahashi et al., 1995).

Glyceraldehyde-3-phosphate dehydrogenase (EC 1.2.1. 12) was measured following the increase in $\mathrm{NADH}$ concentration in $85 \mathrm{mM}$ potassium-phosphate buffer (PPB), $\mathrm{pH} 7.6$, with $3 \mathrm{mM}$ DTE, $0.7 \mathrm{mM} \mathrm{NAD}^{+}$and $10-50 \mu \mathrm{l}$ of cell-free extract. The reaction was started with $1.5 \mathrm{mM}$ glyceraldehyde-3-phosphate.

Phosphoglycerate kinase activity (EC 2.7.2.3) was measured in $84 \mathrm{mM}$ TEA-HCl, $\mathrm{pH} 7.6,1.3 \mathrm{mM} \mathrm{MgCl}_{2}, 0.26 \mathrm{mM}$ $\mathrm{NADH}, 1.6 \mathrm{U} \mathrm{ml}^{-1}$ glyceraldehyde-3-phosphate dehydrogenase, $2.5 \mathrm{mM}$ ATP and $10-50 \mu \mathrm{l}$ of cell-free extract. The reaction was started with 10-20 mM 3-phosphoglycerate.

Pyruvate kinase activity (EC 2.7.1.40) was measured in $69 \mathrm{mM}$ Tris- $\mathrm{HCl}, \mathrm{pH} 7.6$, with $3 \mathrm{mM}$ DTE, $0.33 \mathrm{mM} \mathrm{NADH}$, $1.6 \mathrm{mM}$ phosphoenolpyruvate, $1.3 \mathrm{mM} \mathrm{MgCl}_{2}, 0.5 \mathrm{U} \mathrm{ml}^{-1}$ lactate dehydrogenase, $5 \mathrm{mM} \mathrm{NH}_{4} \mathrm{Cl}$ and $10-100 \mu \mathrm{l}$ of cellfree extract. The reaction was started with $1 \mathrm{mM}$ ADP.

The reaction mixture for pyruvate:acceptor oxidoreductase (pyruvate synthase; EC 1.2.7.1) contained $88 \mathrm{mM}$ Tris- $\mathrm{HCl}$, $\mathrm{pH} 7.6,0.1 \mathrm{mM}$ coenzyme A, $2 \mathrm{mM}$ benzyl viologen $\left(1,1^{\prime}-\right.$ dibenzyl-4,4'-bipyridinium-dichloride, $\varepsilon_{578 \mathrm{~nm}}=865 \mathrm{mM}^{-1} \mathrm{~cm}^{-1}$ ) pre-reduced with $\sim 10 \mu \mathrm{M}$ sodium-dithionite, and $10-50 \mu \mathrm{l}$ of cell-free extract. The reaction was started with $20 \mathrm{mM}$ sodium pyruvate (modified after Williams et al., 1987; Uyeda and Rabinowitz, 1971).

Hydrogen:acceptor oxidoreductase (hydrogenase; EC 1.18.99.1) was measured in the same way as pyruvate: acceptor oxidoreductase except that pyruvate and coenzyme A were omitted and that headspace and buffer were satu- rated with $\mathrm{H}_{2}$. The reaction was started with $10-50 \mu \mathrm{l}$ of cell-free extract (modified after Diekert and Thauer, 1978).

Formate dehydrogenase (1.2.1.2) was measured in the direction of $\mathrm{CO}_{2}$ and $\mathrm{H}_{2}$ formation with benzylviologen, methylviologen, $\mathrm{NAD}^{+}$or $\mathrm{NADP}^{+}$as electron acceptors. One assay mixture contained $90 \mathrm{mM}$ Tris- $\mathrm{HCl}, \mathrm{pH} 7.6,2-50 \mu \mathrm{l}$ of cellfree extract, $1 \mathrm{mM}$ methyl- or benzylviologen or $0.3 \mathrm{mM} \mathrm{NAD}^{+}$ or $\mathrm{NADP}^{+}$. The reaction was initiated by adding $25 \mathrm{mM}$ sodium formate. Addition of dithionite for pre-reduction of viologens was not necessary.

Pyruvate formate lyase was assayed as electron acceptorindependent formation of acetyl $\operatorname{CoA}\left(A_{233}\right)$ from pyruvate.

The assay method for phosphotransacetylase (EC 2.3.1.8) was that of Bergmeyer (1974), following acetyl-coenzyme A formation at $233 \mathrm{~nm}\left(\varepsilon=444 \mathrm{mM}^{-1} \mathrm{~cm}^{-1}\right)$ from $0.33 \mathrm{mM}$ coenzyme A and $3.58 \mathrm{mM}$ acetyl-phosphate in $90 \mathrm{mM}$ Tris- $\mathrm{HCl}$, $\mathrm{pH} 7.6$, with 17-34 $\mu$ l of cell-free extract.

Acetate kinase (EC 2.7.2.1) was measured discontinuously by colorimetric determination of acetyl-phosphate decrease (modified after Nishimura and Griffith, 1981). An assay mixture of $3 \mathrm{ml}$ contained $80 \mathrm{mM}$ Tris- $\mathrm{HCl}, \mathrm{pH} 7.6,3 \mathrm{mM}$ acetyl-phosphate, $5 \mathrm{mM}$ ADP, $5 \mathrm{mM} \mathrm{MgCl}_{2}$ and $150 \mu \mathrm{l}$ of cell-free extract in rubber-stoppered, $\mathrm{N}_{2}$-gassed $4 \mathrm{ml}$ glass vials. Samples of $400 \mu \mathrm{l}$ volume were taken at regular intervals with microlitre syringes and mixed with $300 \mu \mathrm{l}$ of a $1.6 \mathrm{M}$ hydroxylamine solution adjusted to $\mathrm{pH} 7.0$. After $5 \mathrm{~min}, 300 \mu \mathrm{l}$ of a $10 \% \mathrm{FeCl}_{3}$ solution in $1.36 \mathrm{M} \mathrm{HCl} / 0.4 \mathrm{M}$ trichloroacetic acid was added, and the absorption at $535 \mathrm{~nm}$ was recorded after an additional incubation for $5 \mathrm{~min}$. Calibration curves were prepared with 0-3 $\mathrm{mM}$ acetyl-phosphate.

\section{Analytical methods}

Glucose, fatty acids and alcohols were analysed by gas chromatography (Platen and Schink, 1987) or by highperformance liquid chromatography (HPLC) (Klebensberger et al., 2006) using an Aminex HPX-87H ion-exchange column (Bio-Rad) and an LC-10AT vp pump (Shimadzu).

Methane and molecular hydrogen were quantified by gas chromatography (Platen and Schink, 1987; Friedrich and Schink, 1993).

Protein concentrations were determined by the microprotein assay (Bradford, 1976) with bovine serum albumin as standard.

\section{Chemicals}

All chemicals were of analytical or reagent grade quality and were obtained from Boehringer (Mannheim, Germany), Eastman Kodak (Rochester, NY, USA), Fluka (Neu-Ulm, Germany), Merck (Darmstadt, Germany), Pharmacia (Freiburg, Germany), Serva (Heidelberg, Germany) and Sigma (Deisenhofen, Germany). Gases were purchased from Messer-Griesheim (Darmstadt, Germany), and Sauerstoffwerke Friedrichshafen (Friedrichshafen, Germany).

\section{Acknowledgements}

The authors want to thank Dr Werner Hofer, Konstanz, for numerous helpful suggestions to improve our enzyme analy- 
sis techniques, and Elisabeth Kayser for technical help with growth experiments. This study was supported by a research grant of the National Science Foundation, Washington, USA, to B.M.G., and by research funds provided by the University of Konstanz, Germany.

\section{References}

Altschul, S.F., Gish, W., Miller, W., Myers, E.W., and Lipman, D.J. (1990) Basic local alignment search tool. J Mol Biol 215: 403-410.

Amann, R., Fuchs, B.M., and Behrens, S. (2001) The identification of microorganisms by fluorescence in situ hybridisation. Curr Opin Biotechnol 12: 231-236.

Amann, R.I., Ludwig, W., and Schleifer, K.H. (1995) Phylogenetic identification and in situ detection of individual microbial cells without cultivation. Microbiol Rev 59: 143169.

Bergmeyer, H.U. (1974) Methoden der Enzymatischen Analyse, 3rd edn. Weinheim, Germany: Verlag Chemie.

Bradford, M.M. (1976) A rapid and sensitive method for the quantification of microgram quantities of protein utilizing the principle of protein-dye binding. Anal Biochem 72: 248254.

Brune, A., and Schink, B. (1990) Pyrogallol-to-phloroglucinol conversion and other hydroxyl-transfer reactions catalyzed by cell extracts of Pelobacter acidigallici. J Bacteriol 172: 1070-1076.

Bruns, A., Cypionka, H., and Overmann, J. (2002) Cyclic AMP and acyl homoserine lactones increase the cultivation efficiency of heterotrophic bacteria from the central Baltic Sea. Appl Environ Microbiol 68: 3978-3987.

Bussmann, I., Philipp, B., and Schink, B. (2001) Factors influencing the cultivability of lake water bacteria. J Microbiol Methods 47: 41-50.

Chin, K.J., Hahn, D., Hengstmann, U., Liesack, W., and Janssen, P.H. (1999) Characterization and identification of numerically abundant culturable bacteria from the anoxic bulk soil of rice paddy microcosms. Appl Environ Microbiol 65: 5042-5049.

Diekert, G.B., and Thauer, R.K. (1978) Carbon monoxide oxidation by Clostridium thermoaceticum and Clostridium formicoaceticum. J Bacteriol 136: 597-606.

Doré, J., and Bryant, M.P. (1990) Metabolism of one-carbon compounds by the ruminal acetogen Syntrophococcus sucromutans. Appl Environ Microbiol 56: 984-989.

Edwards, U., Rogall, T., Blöcker, H., Emde, M., and Böttger, E.C. (1989) Isolation and direct complete nucleotide determination of entire genes. Characterization of a gene coding for 16S ribosomal RNA. Nucleic Acids Res 17: 7843-7853.

Felsenstein, J. (1989) PHYLIP, phylogeny inference package version 3.57c. Cladistics 5: 164-166.

Friedrich, M.W., and Schink, B. (1993) Hydrogen formation from glycolate driven by reversed electron transport in membrane vesicles of a syntrophic glycolate-oxidizing bacterium. Eur J Biochem 217: 233-240.

Fry, J. (2000) Bacterial diversity and 'unculturables'. Microbiol Today 27: 186-188.

Giovannoni, S.J., Britschgi, T.B., Moyer, C.L., and Field, K.G. (1990) Genetic diversity in Sargasso Sea bacterioplankton. Nature 345: 60-63.
Gunsalus, R.P., Romesser, J.A., and Wolfe, R.S. (1978) Preparation of coenzyme $M$ analogues and their activity in the methyl coenzyme $M$ reductase system of Methanobacterium thermoautotrophicum. Biochemistry 17: 23742377.

Hauck, S., Benz, M., Brune, A., and Schink, B. (2001) Ferrous iron oxidation by denitrifying bacteria in profundal sediments of a deep lake (Lake Constance). FEMS Microbiol Ecol 37: 127-134.

Henckel, T., Friedrich, M., and Conrad, R. (1999) Molecular analyses of the methane-oxidizing microbial community in rice field soil by targeting the genes of the 16S rRNA, particulate methane monooxygenase and methanol dehydrogenase. Appl Environ Microbiol 65: 1980-1990.

lanotti, E.L., Kafkewitz, D., Wolin, M.J., and Bryant, M.P. (1973) Glucose fermentation products of Ruminococcus albus grown in continuous culture with Vibrio succinogenes: changes caused by interspecies transfer of $\mathrm{H}_{2}$. J Bacteriol 114: 1231-1240.

Kemerer, V.F., Griffin, C.C., and Brand, L. (1975) Phosphofructokinase from Escherichia coli. Methods Enzymol. 42: 91-98.

Klebensberger, J., Rui, O., Fritz, E., Schink, B., and Philipp, B. (2006) Cell aggregation of Pseudomonas aeruginosa strain PAO1 as an energy-dependent stress response during growth with sodium dodecyl sulfate. Arch Microbiol 185: 417-427.

Krumholz, L.R., and Bryant, M.P. (1986) Syntrophococcus sucromutans sp. nov. gen. nov. uses carbohydrates as electron donors and formate, methoxybenzenoids or Methanobrevibacter as electron acceptor systems. Arch Microbiol 143: 313-318.

Ludwig, W., Bauer, S.H., Bauer, M., Held, I., Kirchhof, G., Schulze, R., et al. (1997) Detection and in situ identification of representatives of a widely distributed new bacterial phylum. FEMS Microbiol Lett 153: 181-190.

Mclnerney, M.J., Rohlin, L., Mouttaki, H., Kim, U., Krupp, R.S., Rios-Hernandes, L., et al. (2007) The genome of Syntrophus aciditrophicus: life at the thermodynamic limit of microbial growth. PNAS 104: 7600-7605.

Nishimura, J.S., and Griffith, M.J. (1981) Acetate kinase from Veillonella alcalescens. Methods Enzymol 71: 311-316.

Olsen, G.J., Matsuda, H., Hagstrom, R., and Overbeek, R. (1994) fastDNAmL: a tool for construction of phylogenetic trees of DNA sequences using maximum likelihood. Comput Appl Biosci 10: 41-48.

Platen, H., and Schink, B. (1987) Methanogenic degradation of acetone by an enrichment culture. Arch Microbiol 149: 136-141.

Plugge, C.M., Balk, M., Zoetendal, E.G., and Stams, A.J. (2002) Gelria glutamica gen. nov., sp. nov., a thermophilic, obligately syntrophic, glutamate-degrading anaerobe. Int $J$ Syst Evol Microbiol 52: 401-407.

Rainey, A., Janssen, P.H., Wild, D.J.C., and Morgan, H.W. (1991) Isolation and characterisation of an obligately anaerobic, polysaccharolytic, extremely thermophilic member of the genus Spriochaeta. Arch Microbiol 155: 396-401.

Ramakrishnan, B., Lueders, T., Dunfield, P.F., Conrad, R., and Friedrich, M.W. (2001) Effect of soil aggregate size on methanogenesis and archaeal community struc- 
ture in anoxic rice field soil. FEMS Microbiol Ecol 37: 175-186.

Sambrook, J., Fritsch, E.F., and Maniatis, T. (eds) (1989) Molecular Cloning, Vol. 3 appendix, 2nd edn. New York, USA: Cold Spring Harbor Laboratory Press.

Schink, B. (1997) Energetics of syntrophic cooperation in methanogenic cooperation. Microbiol Mol Biol Rev 61: 262-280.

Schink, B., and Zeikus, J.G. (1982) Microbial ecology of pectin decomposition in anoxic lake sediments. J General Microbiol 128: 393-404.

Schink, B., and Stams, A.J.M. (2001) Syntrophism among prokaryotes. In The Prokaryotes: An Evolving Electronic Resource for the Microbiological Community, 3rd edn. Dworkin, M., Falkow, S., Rosenberg, E., Schleifer, K.-H., and Stackebrandt, E. (eds). New York, USA: SpringerVerlag, pp. 25.

Schut, F., de Vries, E.J., Gottschal, J.C., Robertson, B.R., Harder, W., Prins, R.A., and Button, D.K. (1993) Isolation of typical marine bacteria by dilution culture: growth, maintenance, and characteristics of isolates under laboratory conditions. Appl Environ Microbiol 59: 2150-2160.

Sneath, P.H.A. (1986) Endospore-forming Gram-positive rods and cocci. In Bergey's Manual of Systematic Bacteriology, Vol. 2. Sneath, P.H.A., Mair, N.S., Sharpe, M.E., and Holt, J.G. (eds). Baltimore, MD, USA: Williams \& Wilkins; pp. 1104-1207.

Soutschek, E., Winter, J., Schindler, F., and Kandler, O. (1984) Acetomicrobium flavidum, gen. nov. sp. nov., a thermophilic anaerobic bacterium from sewage sludge, forming acetate, $\mathrm{CO}_{2}$ and $\mathrm{H}_{2}$ from glucose. System Appl Microbiol 5: 377-390.

Staley, J.T., and Konopka, A. (1985) Measurement of in situ activities of non-photosynthetic microorganisms in aquatic and terrestrial habitats. Annu Rev Microbiol 39: 321-346.

Stingl, U., Maass, A., Radek, R., and Brune, A. (2004) Symbionts of the gut flagellate Staurojoenina sp. from Neotermes cubanus represent a novel, termite-associated lineage of Bacteroidales: description of 'Candidatus Vestibaculum illigatum'. Microbiology 150: 2229-2235.

Takahashi, N., Kalfas, S., and Yamada, T. (1995) Phosphorylating enzymes involved in glucose fermentation by Actinomyces naeslundii. J Bacteriol 177: 5806-5811.

Tewes, F.J., and Thauer, R.K. (1980) Regulation of ATP synthesis in glucose fermenting bacteria involved in interspecies hydrogen transfer. In Anaerobes and Anaerobic
Infections. Gottschalk, G., Pfennig, N., and Werner, H. (eds). Stuttgart, Germany: G. Fischer, pp. 97-104.

Thauer, R.K., Jungermann, K., and Decker, K. (1977) Energy conservation in chemotrophic anaerobic bacteria. Bacteriol Rev 41: 100-180.

Uyeda, K., and Rabinowitz, J.C. (1971) Pyruvate-ferredoxin oxidoreductase III. Purification and properties of the enzyme. J Biol Chem 246: 3111-3119.

Wagner, M., Loy, A., Nogueira, R., Purkhold, U., Lee, N., and Daims, H. (2002) Microbial community composition and function in wastewater treatment plants. Antonie Van Leeuwenhoek 81: 665-680.

Wallrabenstein, C., and Schink, B. (1994) Evidence of reversed electron transport in syntrophic butyrate oxidation by Syntrophomonas wolfei and Syntrophus buswellii. Arch Microbiol 162: 136-142.

Weisburg, W.G., Barns, S.M., Pelletier, D.A., and Lane, D.J. (1991) 16S ribosomal DNA amplification for phylogenetic study. J Bacteriol 173: 697-703.

Widdel, F., and Bak, F. (1992) Gram-negative mesophilic sulfate-reducing bacteria. In The Prokaryotes. Balows, A., Trüper, H.G., Dworkin, M., Harder, W., and Schleifer, K.H. (eds). Berlin, Germany: Springer Verlag, pp. 3352-3378.

Widdel, F., Kohring, G.W., and Mayer, F. (1983) Studies on dissimilatory sulfate-reducing bacteria that decompose fatty acids. III. Characterization of the filamentous gliding Desulfonema limicola gen. nov. sp. nov., and Desulfonema magna sp. nov. Arch Microbiol 134: 286-294.

Williams, K., Lowett, P.N., and Leadlay, P.F. (1987) Purification and characterization of pyruvate: ferredoxin oxidoreductase from the anaerobic protozoon Trichomonas vaginalis. Biochem J 246: 529-536.

Winogradsky, S.N. (1949) Microbiologie du sol. Problèmes et méthodes. Paris, France: Masson et Cie.

Wood, W.A. (1971) Assay of enzymes representative of metabolic pathways. Methods Microbiol 6A: 411-424.

Yoon, J.H., Kang, S.S., Lee, K.C., Kho, Y.H., Choi, S.H., Kang, K.H., and Park, Y.H. (2001) Bacillus jeotgali sp. nov., isolated from jeotgal, Korean traditional fermented seafood. Int J Syst Evol Microbiol 51: 1087-1092.

Zeikus, J.G. (1977) The biology of methanogenic bacteria. Bacteriol Rev 41: 514-541.

Zeikus, J.G. (1983) Metabolic communication between biodegradative populations in nature. In Microbes in Their Natural Environments. Slater, J.H., Whittenbury, R., and Wimpenny, J.W.T. (eds). Soc Gen Microbiol Symp 34: 423462. Cambridge, UK: Cambridge University Press. 